\title{
Multi-Year Plan for Validation of EnergyPlus Multi-Zone HVAC System modeling using ORNL's Flexible Research Platform
}

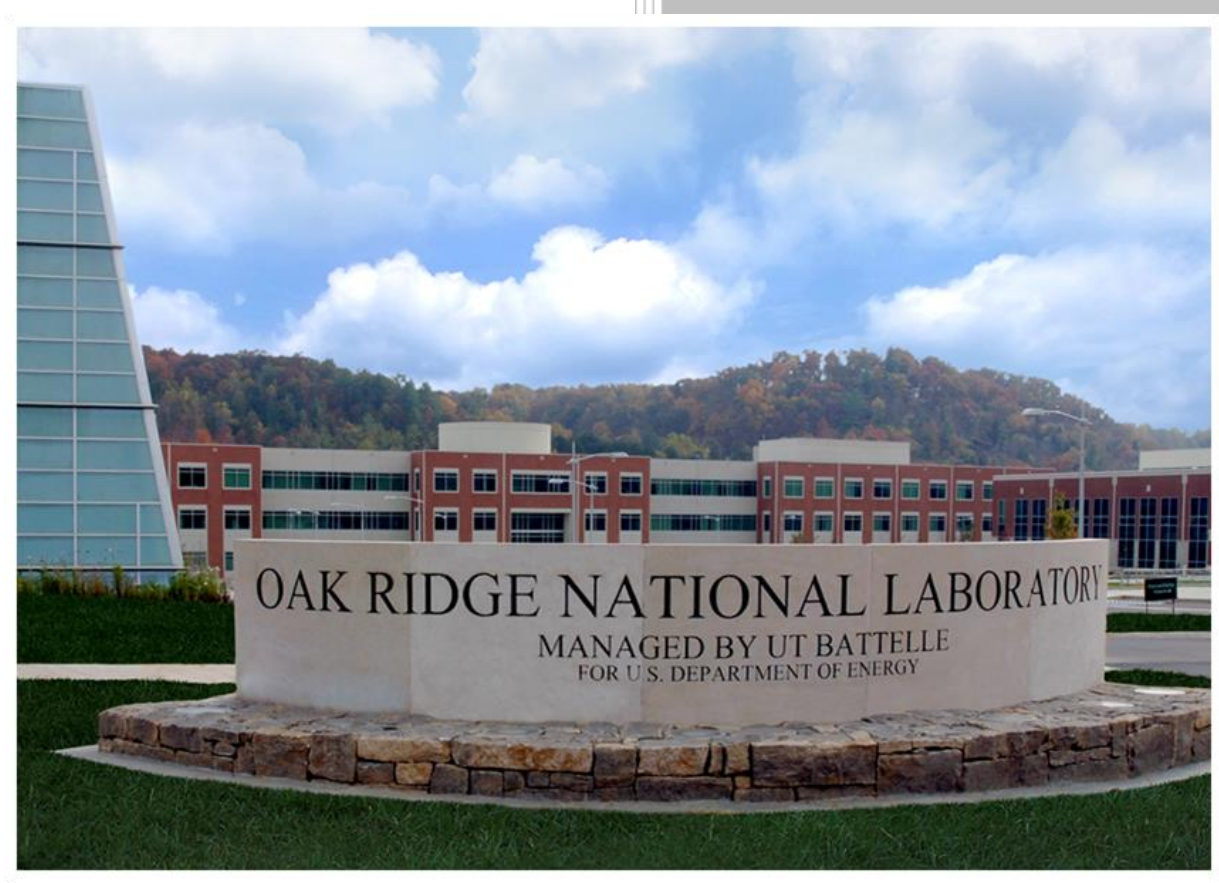

Piljae Im, PhD Mahabir Bhandari, $\mathrm{PhD}$ Joshua New, PhD 


\title{
DOCUMENT AVAILABILITY
}

Reports produced after January 1, 1996, are generally available free via US Department of Energy (DOE) SciTech Connect.

Website http://www.osti.gov/scitech/

Reports produced before January 1, 1996, may be purchased by members of the public from the following source:

\author{
National Technical Information Service \\ 5285 Port Royal Road \\ Springfield, VA 22161 \\ Telephone 703-605-6000 (1-800-553-6847) \\ TDD 703-487-4639 \\ Fax 703-605-6900 \\ E-mail info@ntis.gov \\ Website http://www.ntis.gov/help/ordermethods.aspx
}

Reports are available to DOE employees, DOE contractors, Energy Technology Data Exchange representatives, and International Nuclear Information System representatives from the following source:

Office of Scientific and Technical Information

PO Box 62

Oak Ridge, TN 37831

Telephone 865-576-8401

Fax 865-576-5728

E-mail reports@osti.gov

Website http://www.osti.gov/contact.html

This report was prepared as an account of work sponsored by an agency of the United States Government. Neither the United States Government nor any agency thereof, nor any of their employees, makes any warranty, express or implied, or assumes any legal liability or responsibility for the accuracy, completeness, or usefulness of any information, apparatus, product, or process disclosed, or represents that its use would not infringe privately owned rights. Reference herein to any specific commercial product, process, or service by trade name, trademark, manufacturer, or otherwise, does not necessarily constitute or imply its endorsement, recommendation, or favoring by the United States Government or any agency thereof. The views and opinions of authors expressed herein do not necessarily state or reflect those of the United States Government or any agency thereof. 


\title{
MULTIYEAR PLAN FOR VALIDATION OF ENERGYPLUS MULTI- ZONE HVAC SYSTEM USING ORNL'S FLEXIBLE RESEARCH PLATFORMS
}

Piljae Im, PhD

Mahabir Bhandari, PhD

Joshua New, PhD

Date Published: August 2016

\author{
Prepared by \\ OAK RIDGE NATIONAL LABORATORY \\ Oak Ridge, TN 37831-6283 \\ managed by \\ UT-BATTELLE, LLC \\ for the \\ US DEPARTMENT OF ENERGY \\ under contract DE-AC05-00OR22725
}





\section{CONTENTS}

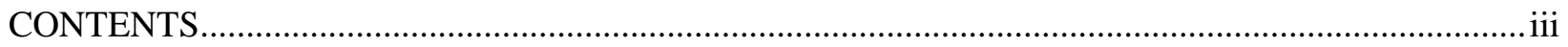

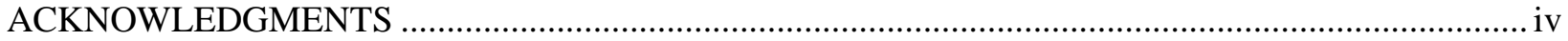

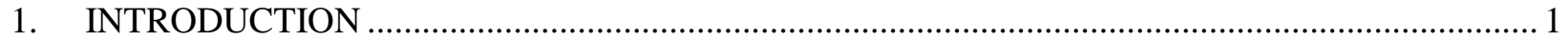

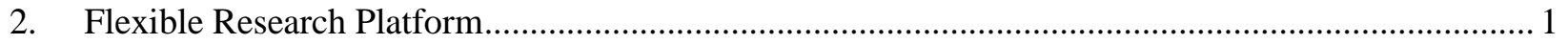

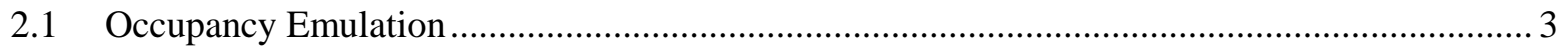

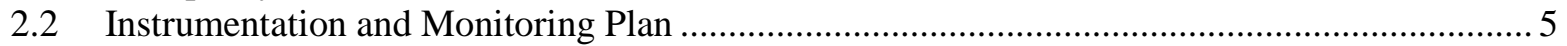

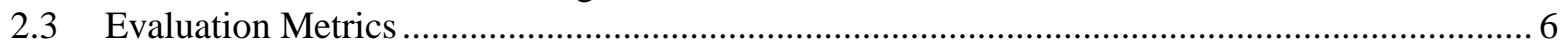

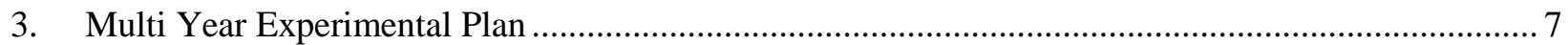

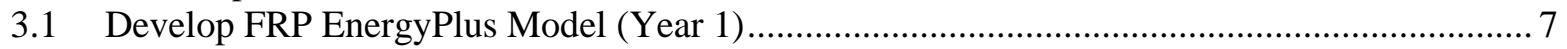

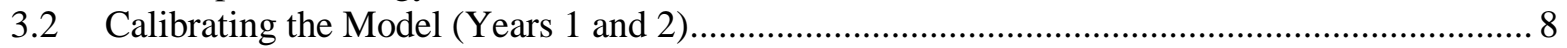

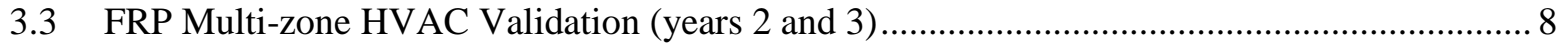

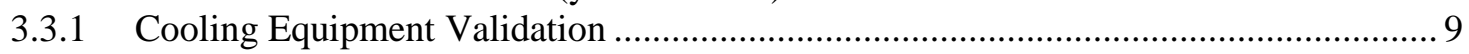

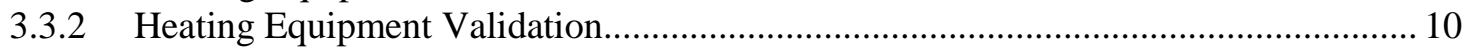

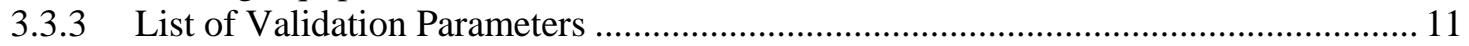




\section{ACKNOWLEDGMENTS}

This material is based upon work supported by the U.S. Department of Energy, Office of Science, and Building Technologies Office. This research used resources of the Oak Ridge National Laboratory Building Technologies Research and Integration (BTRIC), which is a DOE Office of Science User Facility. This work was funded by field work proposal CEBT105 under DOE Building Technology Office Activity Numbers BT0302000 and BT0305000. We would like to thank Amir Roth, ASHRAE Standing Standards Project Committee 140 (SSPC 140), and members of the Technical Advisory Group (TAG) for their review of this project. ORNL is managed by UT-Battelle, LLC, for DOE under contract DE-AC05-00OR22725. This manuscript has been authored by UT-Battelle, LLC, under Contract Number DEAC05-00OR22725 with DOE. The United States Government retains and the publisher, by accepting the article for publication, acknowledges that the United States Government retains a non-exclusive, paidup, irrevocable, world-wide license to publish or reproduce the published form of this manuscript, or allow others to do so, for United States Government purposes. 


\section{INTRODUCTION}

This document describes the Oak Ridge National Laboratory (ORNL) multiyear experimental plan for validation and uncertainty characterization of whole-building energy simulation for a multi-zone research facility using a traditional rooftop unit (RTU) as a baseline heating, ventilating, and air conditioning (HVAC) system. The project's overarching objective is to increase the accuracy of energy simulation tools by enabling empirical validation of key inputs and algorithms. Doing so is required to inform the design of increasingly integrated building systems and to enable accountability for performance gaps between design and operation of a building. The project will produce documented data sets that can be used to validate key functionality in different energy simulation tools and to identify errors and inadequate assumptions in simulation engines so that developers can correct them.

ASHRAE Standard 140, Method of Test for the Evaluation of Building Energy Analysis Computer Programs (ASHRAE 2004), currently consists primarily of tests to compare different simulation programs with one another. This project will generate sets of measured data to enable empirical validation, incorporate these test data sets in an extended version of Standard 140, and apply these tests to the Department of Energy's (DOE) EnergyPlus software (EnergyPlus 2016) to initiate the correction of any significant deficiencies. The fitness-for-purpose of the key algorithms in EnergyPlus will be established and demonstrated, and vendors of other simulation programs will be able to demonstrate the validity of their products. The data set will be equally applicable to validation of other simulation engines as well.

\section{FLEXIBLE RESEARCH PLATFORM}

As a part of a multi-laboratory collaborative project, an existing ORNL flexible research platform (FRP) is being used to validate the modeling of the operation of multi-zone HVAC systems. The FRPs at ORNL are part of a multiyear project that has the goal of installing temporary, instrumented baseline test buildings on two permanent FRPs consisting of slabs and a steel superstructure (Fig. 1a). The single-story FRP, with a footprint of 40 by $60 \mathrm{ft}(12$ by $18 \mathrm{~m}$ ) (Fig. 1b), and the two-story FRP, with a footprint of 40 by $40 \mathrm{ft}$ ( 12 by $12 \mathrm{~m}$ ) (Fig. 1c), can be used to physically simulate light commercial buildings common in the nation's existing building stock. In particular, the two-story FRP was constructed to resemble and perform similarly to the late 1970s-era medium office building common in the 10-county region surrounding the Buildings Hub located at the Philadelphia Naval Yard.

The FRPs are an unoccupied research apparatus in which occupancy is emulated by process control of lighting, humidifiers for human-based latent loading, and a heater for miscellaneous electrical loads (MELs). The emulation minimizes human-occupancy-based interference with the building, which is one of the main sources of uncertainty in building modeling input data. Ground heat transfer is another source of uncertainty due to the unavailability of the deep ground temperature. To reduce this uncertainty, 12" Geofoam EPS46 (R4.6 per inch - $\mathrm{R}_{\mathrm{SI}} 0.76$ per inch) insulation was installed in the floor. The added insulation would make the floor to ground heat transfer close to adiabatic. Additionally, piping around the perimeter is also provided so that the cold or water can be circulated through these pipes to maintain the desired ground temperature. Appendix $\mathrm{C}$ shows the piping layout and sensor locations for temperature and heat flux measurements. However, due to cost constraints of heating/cooling water equipment for the hot/cold water supply, these pipes are not active currently. These test buildings are exposed to natural weather conditions for research and development leading to system- and building-level advanced energy efficiency solutions for new and retrofit applications. On these test buildings, tune-ups, retrofits, or alternative building components or systems can be implemented; and the data gathered, with and without the modifications, can be used to characterize the baseline energy performance and the energy savings from the tune-up/retrofit or alternative system/component. In addition, a dedicated weather station (Fig. 2) 
is installed on the roof of the two-story FRP so that actual weather data can be used in performance analysis and energy modeling.

The two-story FRP is being used for this project. The systems in the two-story FRP are multi-zone HVAC systems with ten thermal zones (eight perimeter zones and two core zones) that can be controlled individually. Energy performance in the FRPs has been monitored since the summer of 2013 by $\sim 1,071$ sensors, most of which are recorded at 30-second intervals. Henceforth, the two-story FRP will be referred to as the FRP in this project.

The multi-zone HVAC system used for the first experimental design incorporates a 12.5 ton RTU and a natural gas furnace. The RTU has a 9.6 energy efficiency rating (EER). The furnace has an $81 \%$ annual fuel utilization efficiency (AFUE) rating. Each room in the FRP has a variable-air-volume (VAV) box with electric resistance reheat. The central fan in the air-handling unit draws return air from each room. The original intake for the fresh air in the RTU was blocked for the test and will remain as-is. An exhaust fan with a known air flow rate (in cubic feet per minute) is located on each floor and operates continuously. The Johnson Controls Metasys system, a dedicated energy management control system, is deployed in the FRP; and the room set point temperature, schedule, and other controls were predefined through the Metasys system.

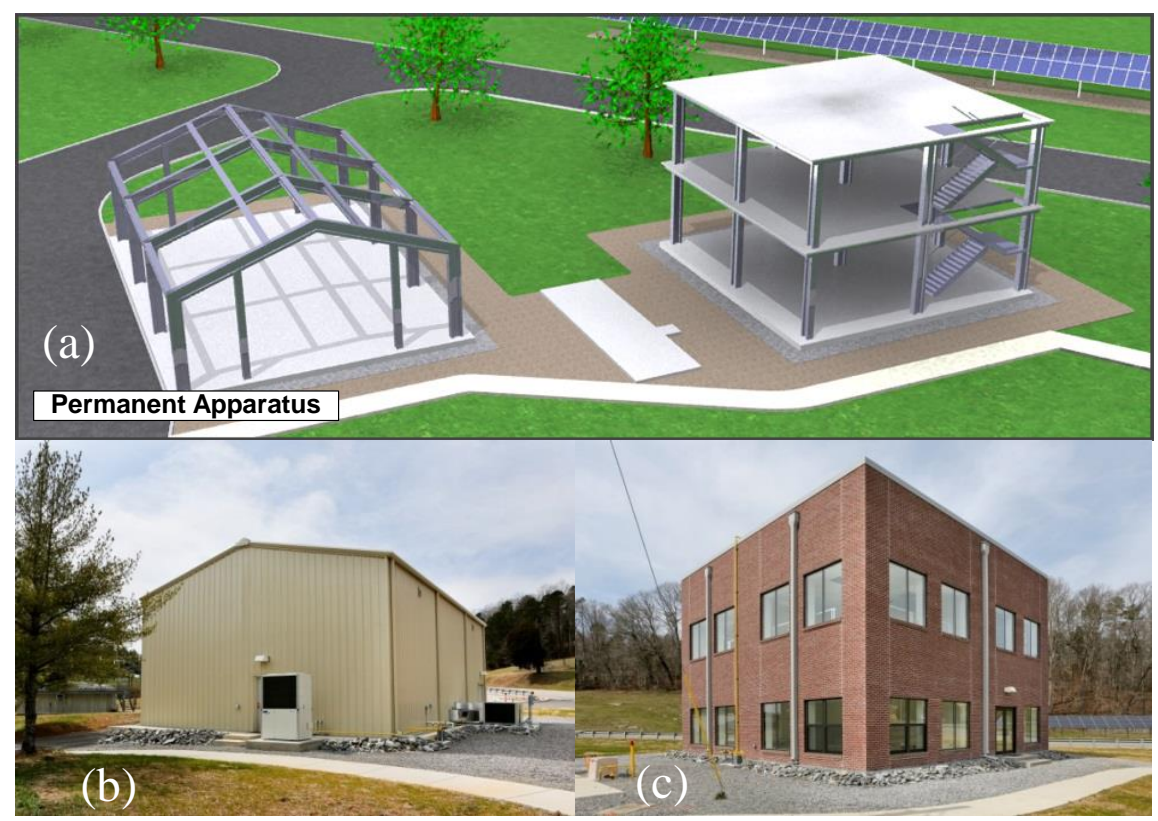

Fig. 1. ORNL flexible research platforms (FRPs): (a) FRP permanent structures, showing slabs and steel superstructures; (b) single-story FRP and (c) two-story FRP.
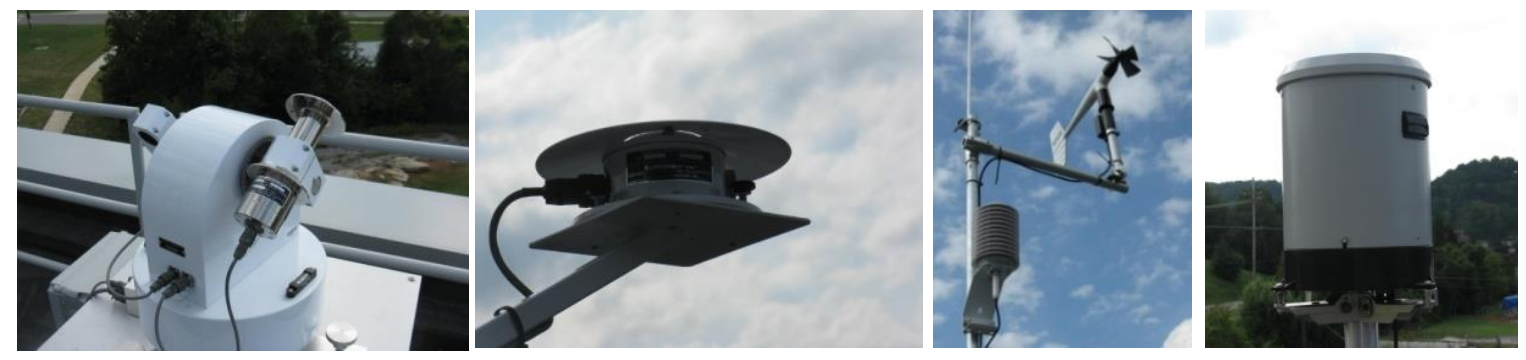

Fig. 2. Weather station on the roof of the two-story FRP. 
The RTU is programmed to maintain a constant discharge air temperature at $57^{\circ} \mathrm{F}\left(14^{\circ} \mathrm{C}\right)$. The natural gas furnace engages if the building mixed-air temperature drops below $57^{\circ} \mathrm{F}\left(14^{\circ} \mathrm{C}\right)$. As long as the discharge air is at least $57^{\circ} \mathrm{F}\left(14^{\circ} \mathrm{C}\right)$, the zone electric heat in the VAV boxes activates to provide the necessary perimeter heat. The baseline envelope and HVAC characteristics of the FRP test building are shown in Table 1.

Table 1. Characteristics of the test building

\begin{tabular}{|c|c|}
\hline \multicolumn{2}{|l|}{ General characteristics } \\
\hline Location & Oak Ridge, Tennessee \\
\hline Building width & $40 \mathrm{ft}(12.2 \mathrm{~m})$ \\
\hline Building length & $40 \mathrm{ft}(12.2 \mathrm{~m})$ \\
\hline Story height (floor to floor) & $14 \mathrm{ft}(4.3 \mathrm{~m})$ \\
\hline Number of floors & 2 \\
\hline Number of thermal zones & 10 ( 8 perimeter and 2 core $)$ \\
\hline \multicolumn{2}{|l|}{ Construction characteristics } \\
\hline Wall structure & Concrete masonry units with face brick \\
\hline Wall insulation & Fiberglas $\mathrm{R}_{\mathrm{US}}-11\left(\mathrm{Btu} /\left(\mathrm{h}-\mathrm{F}-\mathrm{ft}^{2}\right)\left(\mathrm{R}_{\mathrm{SI}}-1.9(\mathrm{~W} / \mathrm{m}-\mathrm{K})\right)\right.$ \\
\hline Floor & Slab-on-grade \\
\hline Roof structure & Metal deck with polyisocyanurate and ethylene proplylene diene monomer \\
\hline Roof insulation & Polyisocyanurate $\mathrm{R}_{\mathrm{US}}-18\left(\mathrm{R}_{\mathrm{SI}}-3.17\right)$ \\
\hline Windows & Aluminum frame, double-pane, clear glazing \\
\hline Window-to-wall ratio & $28 \%$ \\
\hline \multicolumn{2}{|c|}{ Systems and equipment characteristics } \\
\hline Lighting power density & $0.85 \mathrm{~W} / \mathrm{ft}^{2}\left(9.2 \mathrm{~W} / \mathrm{m}^{2}\right)$ with lighting on/off schedule \\
\hline Equipment power density & $1.3 \mathrm{~W} / \mathrm{ft}^{2}\left(14.0 \mathrm{~W} / \mathrm{m}^{2}\right)$ with on/off schedule \\
\hline Baseline systems & Rooftop variable-air-volume unit with electric reheat, natural gas furnace \\
\hline $\begin{array}{l}\text { Rooftop unit (RTU) cooling } \\
\text { capacity }\end{array}$ & 12.5 ton \\
\hline RTU efficiency & 9.7 EER \\
\hline Natural gas furnace efficiency & $81 \%$ AFUE \\
\hline
\end{tabular}

\subsection{OCCUPANCY EMULATION}

The occupancy of the FRP is emulated using the typical occupancy schedule and power density within existing office buildings as defined by ASHRAE Standard 90.1-1989, Energy Efficient Design of New Buildings Except Low-Rise Residential Buildings (ASHRAE 1989); Huang et al. (1991), 481 Prototypical Commercial Buildings for 20 Urban Market Areas; Huang and Franconi (1999), Commercial Heating and Cooling Loads Component Analysis; and Pacific Northwest National Laboratory (1990). To emulate occupancy, sensible and latent heat additions are estimated and simulated using portable heaters and humidifiers with preprogrammed timers to match hourly profiles. The sensible heat from occupants and from other building equipment such as computers, copiers, and other office machinery is likewise simulated with portable heaters and timers. The lighting fixtures are turned on and off based on the preprogrammed operational schedule. Fig. 3 shows the defined lighting and occupancy schedule based on the literature review, and Fig. 4 illustrates how the heater, humidifier, and lighting fixtures are controlled. The lighting and other occupancy schedules shown here will remain as-is throughout the initial experiment design and will subsequently be modeled in EnergyPlus. Appendix E describes further 
regarding the occupancy emulation and also provides the comparison between the target and emulated values. Before the first set of validation test, the existing internal heaters will be replaced with new units as the existing ones have been operated several years, and the comparison between target and emulated loads will be compared again.

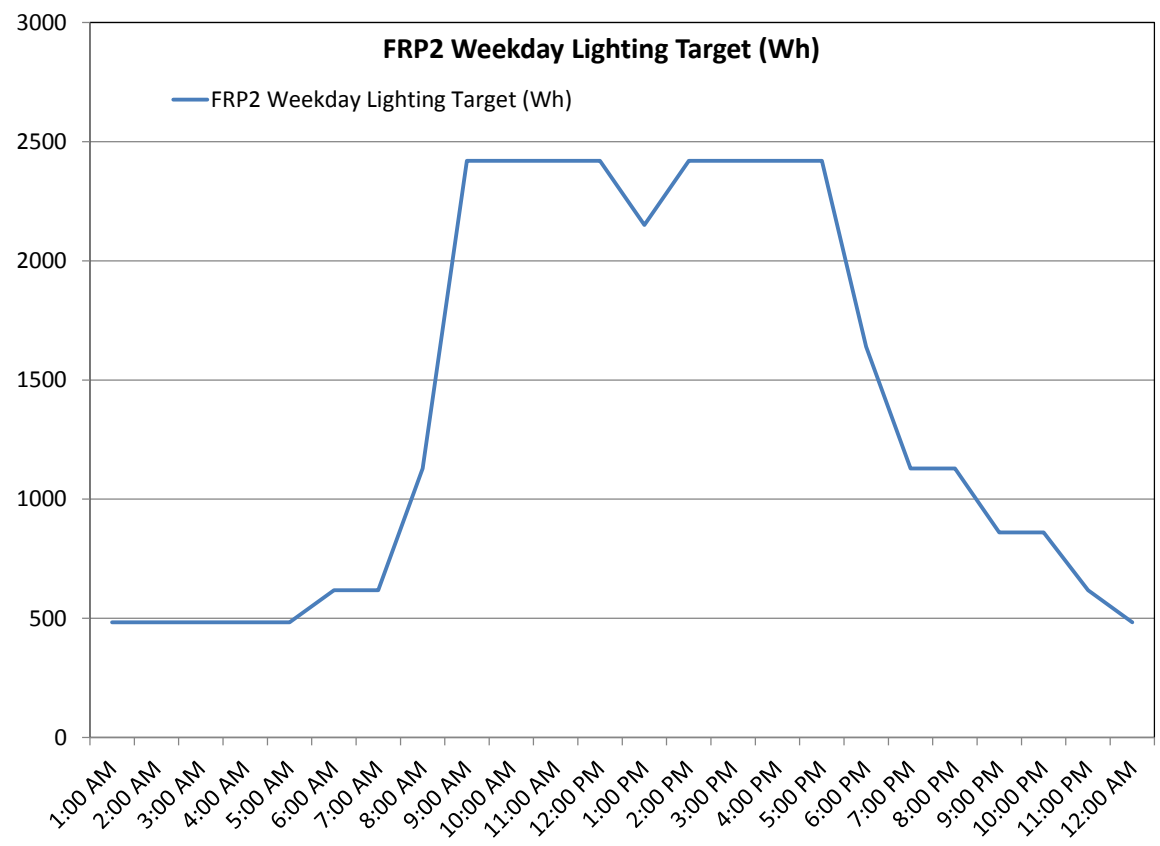

(a)

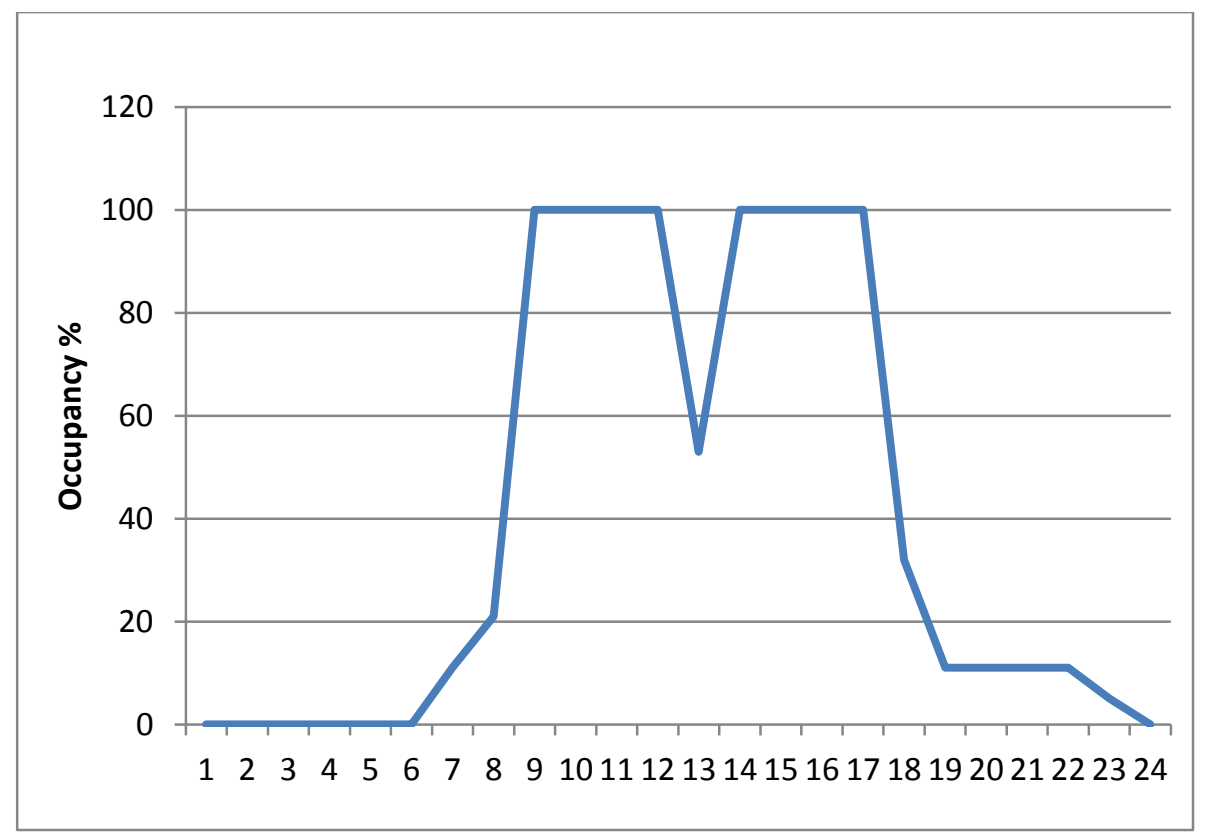

(b)

Fig. 3. Weekday lighting (a) and occupancy (b) schedule. 


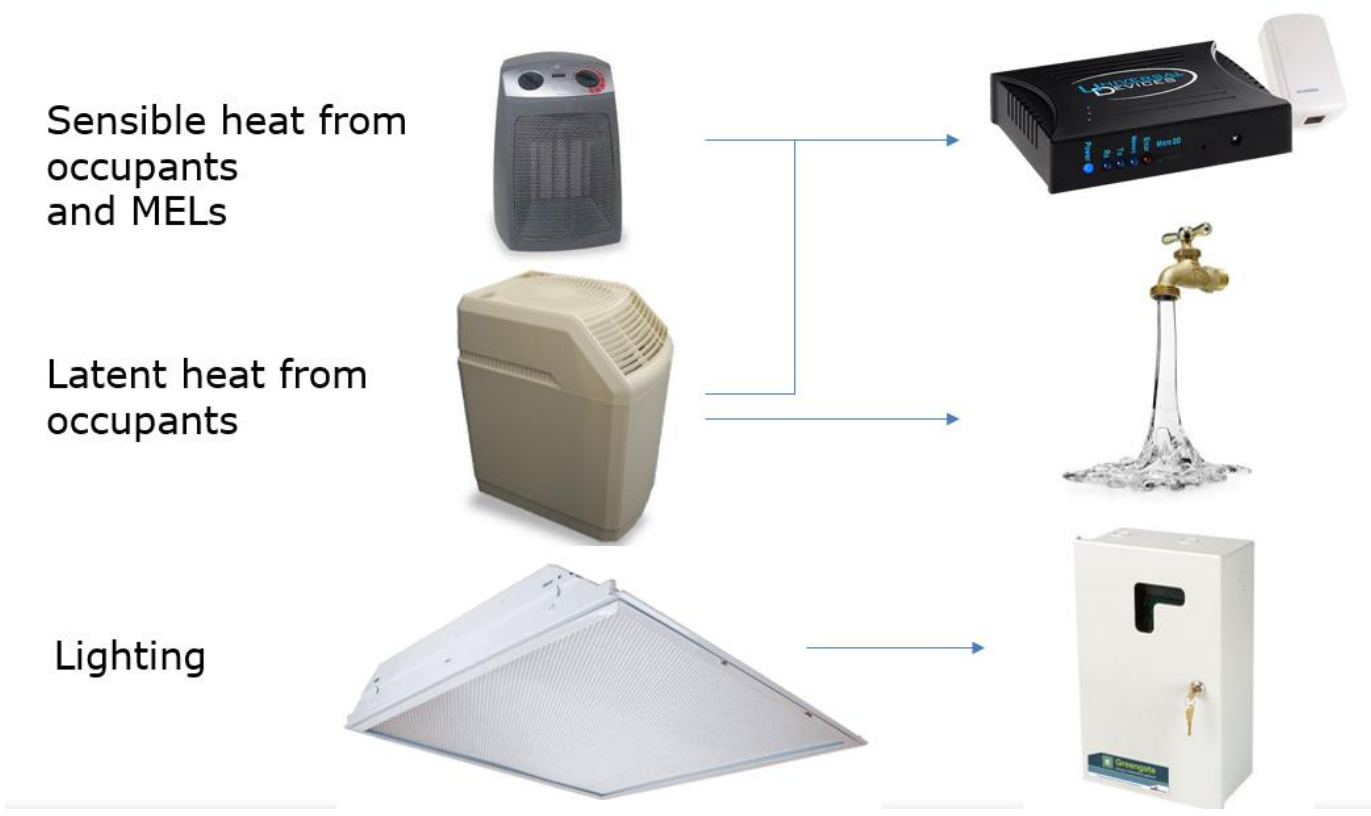

Fig. 4. Equipment and controls used for lighting, miscellaneous electrical loads, and occupancy gains and schedules.

\subsection{INSTRUMENTATION AND MONITORING PLAN}

Data acquisition hardware - including 1 master cabinet, 4 peripheral cabinets, 256 thermistor channels, 256 single-ended voltage channels, 100 thermocouple channels, and 64 frequency input (or $5 \mathrm{~V}$ ) control channels - is currently deployed in the FRP. Fig. 5 shows the layout and location of the HVAC systems and measured parameters. Rooms 102 through 106 are located at the first floor and rooms 202 through 206 are on the second floor. The measurements include the zone set point temperature and humidity, supply and return air temperature and flow rates, and energy consumption of individual components including compressor, condenser, supply fan, VAV reheating. In addition to the measured parameters shown in Fig. 5, the heat fluxes and temperatures at all the envelope surfaces are measured. The measured data are used for building model calibration. The sensors used for monitoring are calibrated, and the data are recorded at $15 \mathrm{~min}$ intervals. The set points and control sequences are modified depending on the parameters being validated. The following list shows the numbers of sensors installed for the RTU performance measurement.

- 35 temperature/relative humidity $(\mathrm{RH})$ probes (rooms, supply air duct, return and mixed air, VAV box, exhaust air, and outdoor air [OA])

- Ten Globe thermometers for mean radiant temperature

- Six refrigerant-side immersion thermistors

- Six refrigerant-side pressure transducers

- Two refrigerant mass flow sensors

- One natural gas mass flow meter

- Two airflow measurement stations

- 16 HVAC power measurements

- 21 building end-use power measurements 


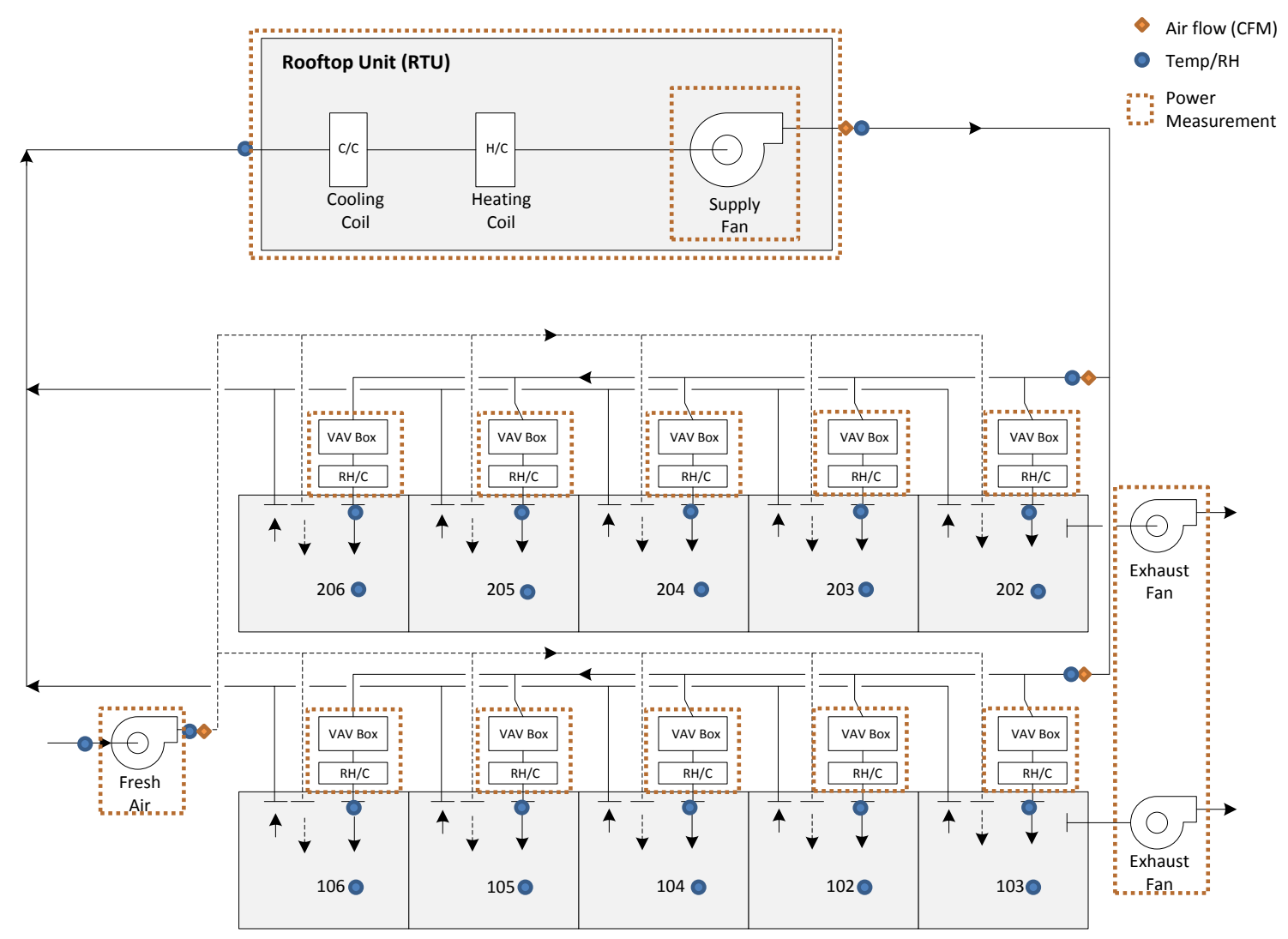

Fig. 5. Layout of measurement parameters.

\subsection{EVALUATION METRICS}

The following metrics are used in this validation study.

1. Cooling and heating energy delivered (building level)

- Cooling and heating delivered load are calculated based on air-side measurements.

- Cooling delivered load will be calculated based on temperature difference before and after cooling coil at the RTU and measured CFM.

- Heating delivered loads are the sum of delivered heating loads by NG heating (if any) and zone electric reheating. The delivered heating loads by NG heating will be calculated based on temperature difference before and after heating coil at the RTU and measured $\mathrm{CFM}$. The delivered heating loads by electric reheating will be the same with the electricity use for the zone reheating as the COP of the reheating equals to 1 .

2. Zone temperature and RH (zone level)

- Zone temperature, $\mathrm{RH}$, and mean radiant temperature are monitored.

3. Supply and return air temperatures (HVAC unit level) 


\section{Supply air flow (HVAC unit level)}

5. HVAC electricity and natural gas use (primary and source energy; building level)

Separate validation criteria for these metrics will be defined. Hourly and monthly calibration criteria per ASHRAE Guideline 14-2014, Measurement of Energy, Demand and Water Savings (ASHRAE 2002), will be used for energy consumption ( 1 and 5 above). For validation analysis ( 2,3 and 4 above), a qualitative approach will be used to compare the measured and simulated values. Average errors will be evaluated, including daily maximum and minimum temperatures and RH.

To generate a test data set for the expansion of ASHRAE 140, this project first will document the building characteristics in detail based on premeasured data and observations. In addition, a site-measured, fullyear weather file will be developed and provided with the test data set.

Building characteristics corresponding to simulation input parameters will include, but are not limited to, the following.

1. Building geometry, zone layouts, and window-to-wall ratio

2. Building envelope properties (including the construction and materials for exterior wall, roof, windows, interior wall, floor, slab and windows), including detailed section drawings

3. Building blower door test results (see Appendix F)

4. HVAC system characteristics (type, capacity, efficiency, and generic performance curves)

5. Internal heat gain (plug load, power density, schedule)

6. Lighting fixture characteristics and schedule

7. Heating/cooling set point temperature and setback schedule

8. Occupancy level and schedules

Because the FRP is a real building and not a controlled chamber, there are uncertainties in all the parameters and measurements. These uncertainties will be documented where applicable.

\section{MULTI YEAR EXPERIMENTAL PLAN}

The multiyear experimental plan includes development and calibration of an EnergyPlus model and validation of modeled cooling and heating equipment performance with measured data. A carefully calibrated model of the two-story FRP will be provided as part of this validation study. Component-level, hourly calibration will be performed to ascertain the accuracy of the model before the detailed validation is performed. The following steps, by fiscal year, will be taken during the project.

\subsection{DEVELOP FRP ENERGYPLUS MODEL (YEAR 1)}

An EnergyPlus whole-building model of the two-story FRP will be developed with as-built drawings and an RTU as an HVAC system, the RTU manufacturer's data, and premeasured data (such as those from the blower door test). An as-built, whole-building, EnergyPlus model for the two-story FRP has already been 
developed as part of a previous project. Since the summer of 2015, the building configuration has been modified with a partially retrofitted building wall system, and changes have been made in the fresh air unit. Therefore, the original as-built EnergyPlus model will be updated with the modified building characteristics.

\subsection{CALIBRATING THE MODEL (YEARS 1 AND 2)}

1. From summer 2015 through spring 2016, the FRP has been operated weekly by switching between three different HVAC systems every week. The hourly monitored data from only the RTU system will be used to calibrate the model discussed in Section 3.1.

2. During the summer 2015-spring 2016 monitoring period, the RTU was running with a setback schedule and emulated occupancy. For further calibration, the FRP will be operated as described below, and further calibration will be performed.

a. During summer of FY 2016, the FRP will remain without air conditioning for 3 full days (no lighting/internal gain, all blinds open [i.e., no shading devices], no exhaust fans running). The third-day data will be used for comparison and calibration. This step will ensure the modeling accuracy of building envelope and solar transmission.

b. During summer of FY 2016, the RTU for all ten zones will be run for 3 days without setback. The RTU discharge set point temperature will be fixed (no lighting/internal gain, all blinds open, no OA, no exhaust fan). The third-day data will be used for comparison and calibration.

c. During winter of FY 2017, the FRP will remain without air conditioning for 2 full days (no lighting/internal gain, all blinds open [i.e., no shading devices], no exhaust fans running). The second-day data will be used for comparison and calibration. This step will ensure that the seasonal impacts of envelope modeling are captured accurately.

d. During winter of FY 2017, the RTU for all ten zones will be run for 3 days without setback. The RTU discharge set point temperature will be fixed (no lighting/internal gain, all blinds open, no OA, no exhaust fan). This third-day data will be used for comparison and calibration.

3. Along with the data monitoring, a series of blower door tests for the FRP will be performed for cooling and heating seasons. The results will be used for calibrating the model.

4. The model will be calibrated based on the data measured above. The parameters listed in the evaluation metrics will be used for comparison and calibration.

5. The discrepancies with the initial models will be documented, including the input parameters used for the calibration and how the calibrations were performed.

\subsection{FRP MULTI-ZONE HVAC VALIDATION (YEARS 2 AND 3)}

Once they are calibrated, the performance of the HVAC systems with various outdoor and indoor conditions (e.g., various OA temperature conditions, full- and part-load conditions, thermostat setback schedules) will be measured and verified for consistency using redundant measurements. The resulting data sets will be used for EnergyPlus validation in Task 7 of the project and prepared for submission to ASHRAE for inclusion in Standard 140 as part of Task 8. The HVAC system parameters/variables measured will be selected by the project team based on feedback/input from the project technical advisory group and approved by the DOE Technology Manager. 
ASHRAE 140 provides mechanical cooling/heating base cases CE100 and CH100. However, the building/system specifications for these cases are not consistent with the current FRP setup. The FRP is a two-story building with ten thermal zones exposed to real weather conditions. These cases are not intended to be used with a real building, but only with building energy models. The test conditions for cases CE100 and CH100, including the building envelope requirements, are not suitable for any real building. For example, the wall/roof/floor insulation R-values defined in these cases are $\sim 567 \mathrm{~h} \bullet \mathrm{ft}^{2} \bullet 0^{\circ} \mathrm{F} / \mathrm{Btu}$, and the infiltration rate is zero, which cannot be realized in real buildings. Therefore, the test plan for the multi-zone HVAC validation will refer only to a selected set of ASHRAE 140's HVAC test conditions that can be realized in the current FRP setup.

Given the objective of this validation project is to provide a set of empirical data from a high-fidelity test facility, this would fulfill the objectives.

\subsubsection{Cooling Equipment Validation}

For cooling equipment validation, ASHRAE 140 case CE100, CE 110, CE 120, CE130, CE 150, CE160, and CE165 were reviewed, and they were applied as described or modified as applicable to the FRP. An RTU with a VAV will be used as a cooling season test. The cooling season test will be performed during June/July/August.

\section{Test 1: Cooling Baseline Case (Year 2)}

As a baseline case test, a building as-is will be tested. There will be no other treatments, such as blocking windows, adding additional envelope insulation, and so on. Detailed building envelope characteristics, internal loads, weather data, and HVAC system information will be provided to ensure modeling for multiple domain simulation programs. The testing will include the following other test conditions.

- Window blinds will not be used.

- No sensible or latent internal loads will be used.

- A fixed discharge temperature of $55^{\circ} \mathrm{F}\left(12.7^{\circ} \mathrm{C}\right)$ and no $\mathrm{OA}$ or exhaust air provision (same as CE100) will be set.

- $\quad$ Fixed static pressure will be maintained.

- Room temperature will be maintained at $72^{\circ} \mathrm{F}\left(22.2^{\circ} \mathrm{C}\right)$ with possible minimum dead band. There will be no setback/set-up schedule, no humidity control. Heating will be OFF.

Using these conditions, 1 week during June/July/August will be selected, and 2 days for warming up and 3 days with HVAC operation will be tested.

2. Test 2: Reduced outdoor dry-bulb temperature. (Year 2)

Test 1 includes the Test 2 as this test is performed under real weather condition. Real weather operation will provides wide range of outdoor dry-bulb temperature to be tested during the test.

\section{Test 3: Cooling with increased thermostat set point (Year 2)}

The thermostat set point will be increased to $26.7^{\circ} \mathrm{C}\left(80^{\circ} \mathrm{F}\right)$, and other conditions will be kept the same as in the cooling baseline case. One week during June/July/August will be selected, and 2 days for warming up and 3 days with HVAC operation will be tested.

\section{Test 4: Cooling with low part-load ratio (Year 3)}


A steady partial load will be emulated using heaters. The heater will be used to increase/decrease the cooling load. Other conditions will be kept the same as in the cooling baseline case. One week during June/July/August will be selected, and 2 days for warming up and 3 days with HVAC operation will be tested.

\section{Test 5: Latent load at high sensible heat ratio (Year 3)}

Constant sensible and latent internal loads will be emulated using heaters and humidifiers. Other conditions will be kept the same as in the cooling baseline case. One week during June/July/August will be selected, and 2 days for warming up and 3 days with HVAC operation will be tested.

\section{Test 6: Increased thermostat set point at high sensible heat ratio (Year 3)}

Test 6 will be the same as Test 5 except for an increased zone set point temperature of $26.7^{\circ} \mathrm{C}\left(80^{\circ} \mathrm{F}\right)$. One week during June/July/August will be selected, and 3 days for warming up and 3 days with HVAC operation will be tested.

\section{Test 7: Variation of thermostat set point at high sensible heat ratio (Year 3)}

As a final test, the thermostat set point will be varied by use of a setback. (e.g., 0 through 6 a.m.: $31^{\circ} \mathrm{C} ; 6$ a.m. through 6 p.m.: $75^{\circ} \mathrm{F}\left(24^{\circ} \mathrm{C}\right) ; 6$ p.m. through 12 a.m.: $\left.88^{\circ} \mathrm{F}\left(31^{\circ} \mathrm{C}\right)\right)$. The rest of the test conditions will be the same as in Test 6 . One week during June/July/August will be selected, and 2 days for warming up and 3 days with HVAC operation will be tested.

\subsubsection{Heating Equipment Validation}

For heating season validation, ASHRAE 140 cases HE100, HE 210, HE 220 were reviewed and applied as described or modified as applicable to the FRP. The heating equipment performance test in ASHRAE 140 targets a fuel-fired furnace system, whereas the main heating system in the FRP is electric reheat. Therefore, only a couple of applicable tests will be performed for heating equipment validation. The heating season test will be performed during December/January.

\section{Test 8: Heating baseline case (Year 2)}

As in the cooling baseline case, a building as-is will be tested. There will be no other treatments such as blocking windows, adding additional envelope insulation, and so on. Detailed building envelope characteristics, internal loads, weather data, and HVAC system information will be provided to ensure modeling for multiple domain simulation programs. The following other test conditions will be used.

- Window blinds will not be used.

- No sensible and latent cooling load will be emulated.

- There will be a fixed discharge temperature $\left(57^{\circ} \mathrm{F}\left(14^{\circ} \mathrm{C}\right)\right)$ from the RTU and no OA provision (the same conditions used in the cooling season baseline test).

- Fixed static pressure will be maintained.

- No natural gas furnace will be used. Only reheat will be used. There will be no zone humidity control.

- Room temperature will be maintained at $68^{\circ} \mathrm{F}\left(20^{\circ} \mathrm{C}\right)$ with possible minimum dead band. There will be no setback schedule. 
Under these conditions, one week during December/January will be chosen, and 2 days for warming up and 3 days with HVAC operation will be tested.

\section{Test 9: Heating with setback thermostat (Year 2)}

As a final test, the thermostat set point will be varied using a setback. (e.g., 0 through 6 a.m.: $59^{\circ} \mathrm{F}$ $\left(15^{\circ} \mathrm{C}\right) ; 6$ a.m. through 6 p.m.: $69.8^{\circ} \mathrm{F}\left(21^{\circ} \mathrm{C}\right) ; 6$ p.m. through 12 a.m.: $\left.59^{\circ} \mathrm{F}\left(15^{\circ} \mathrm{C}\right)\right)$. One week during December/January will be chosen, and 2 days for warming up and 3 days with HVAC operation will be tested.

\subsubsection{List of Validation Parameters}

During the series of tests described above, the parameters given in Table 2 will be measured and compared/validated with the EnergyPlus model of the FRP. The parameters will be updated based on further feedback from domain experts and Technical Advisory Group (TAG).

Table 2. Characteristics of the test building

\begin{tabular}{|c|c|c|c|c|}
\hline \# & Parameters & Sub-parameters & Unit & Note \\
\hline \multirow{3}{*}{$\begin{array}{l}1 \\
2 \\
3\end{array}$} & \multirow[t]{3}{*}{ RTU energy use } & $\begin{array}{l}\text { Direct expansion } \\
\text { cooling }\end{array}$ & $\mathrm{W} \cdot \mathrm{h}$ & Two-stage cooling coil \\
\hline & & Evaporative fan & $\mathrm{W} \cdot \mathrm{h}$ & Main supply fan with variable-frequency drive \\
\hline & & $\begin{array}{l}\text { VAV box } \\
\text { (electric reheat) }\end{array}$ & $\mathrm{W} \cdot \mathrm{h}$ & Individual electric reheating for each VAV box \\
\hline 4 & $\begin{array}{l}\text { RTU discharge } \\
\text { temperature }\end{array}$ & & ${ }^{\circ} \mathrm{F}$ & Fixed discharge temperature for RTU \\
\hline 5 & $\begin{array}{l}\text { RTU return air } \\
\text { temperature }\end{array}$ & & ${ }^{\circ} \mathrm{F}$ & Mixed return air temperature from 10 zones \\
\hline 6 & $\begin{array}{l}\text { RTU supply air } \\
\text { flow }\end{array}$ & & CFM & \\
\hline 7 & $\begin{array}{l}\text { Supply air flow for } \\
\text { each zone }\end{array}$ & & CFM & $\begin{array}{l}\text { TBD_ no sensors are available for zone-level } \\
\text { air flow measurement yet }\end{array}$ \\
\hline 8 & $\begin{array}{l}\text { Room temperature } \\
\text { for each zone }\end{array}$ & & ${ }^{\circ} \mathrm{F}$ & $\begin{array}{l}10 \text { measurement points. Temperature sensor is } \\
\text { located in the middle of each zone }\end{array}$ \\
\hline 9 & $\begin{array}{l}\text { Room RH for each } \\
\text { zone }\end{array}$ & & $\%$ & $\begin{array}{l}10 \text { measurement points. RH sensor is located in } \\
\text { the middle of each zone }\end{array}$ \\
\hline
\end{tabular}

$\mathrm{RH}=$ relative humidity 


\section{REFERENCES}

ASHRAE 1989. Energy Efficient Design of New Buildings Except Low-Rise Residential Buildings, ANSI/ASHRAE/IESNA Standard 90.1-1989, American Society of Heating, Refrigerating and AirConditioning Engineers, Atlanta.

ASHRAE 2002. Measurement of Energy and Demand Savings, ASHRAE Guideline 14-2002, American Society of Heating, Refrigeration and Air-Conditioning Engineers, Atlanta.

ASHRAE 2004. Method of Test for the Evaluation of Building Energy Analysis Computer Programs, ASHRAE Standard 140, American Society of Heating, Refrigerating and Air-Conditioning Engineers, Atlanta.

EnergyPlus 2016. EnergyPlus Energy Simulation Software (and supplemental documentation), US Department of Energy, www.energyplus.gov (accessed June 2016).

Huang, J., H. Akbari, L. Rainer, and R. Ritshard 1991. 481 Prototypical Commercial Buildings for 20 Urban Market Areas, LBL-29798, Lawrence Berkeley National Laboratory, Berkeley, Calif.

Huang, J., and E. Franconi 1999. Commercial Heating and Cooling Loads Component Analysis, LBL37208, Lawrence Berkeley National Laboratory, Berkeley, Calif.

PNNL (Pacific Northwest National Laboratory) 1990. Architect's and Engineer's Guide to Energy Conservation In Existing Buildings: Volume 1-Energy Use Assessment and Simulation Methods, PNL7105, Pacific Northwest National Laboratory, Richland, Wash. 


\section{APPENDIX A. TECHNICAL SPECIFICATIONS OF THE SENSORS USED FOR THE MEASUREMENT}

\begin{tabular}{|c|c|c|}
\hline Sensors & Measurement & Accuracy \\
\hline Campbell Sci HC2S3-L & $\begin{array}{l}\text { Temperature/relative } \\
\text { humidity (RH) }\end{array}$ & $\pm 0.1^{\circ} \mathrm{C}$ and $\pm 0.1 \% \mathrm{RH} @ 23^{\circ} \mathrm{C}$ \\
\hline $\begin{array}{l}\text { Continental Controls WNB-3D- } \\
240 \mathrm{P}\end{array}$ & Power & $\pm 0.5 \%$ of reading \\
\hline $\begin{array}{l}\text { Omega } 44031 \text { immersion } \\
\text { thermistor probes }\end{array}$ & Temperature & @ 0 to $70^{\circ} \mathrm{C}$ is $\pm 0.1^{\circ} \mathrm{C}$ \\
\hline $\begin{array}{l}\text { Omega PX409-750-A5V pressure } \\
\text { transducers }\end{array}$ & Pressure & $\pm 0.08 \%$ best straight line maximum \\
\hline Sierra BT620 thermal flowmeter & Gas flow & $\begin{array}{l} \pm 1 \% \text { of full scale (actual gas calibration) and } \\
\pm 1 \% \text { of full scale/ } \pm 3 \% \text { of reading (correlation); } \\
\text { repeatability } \pm 0.2 \% \text { of full scale }\end{array}$ \\
\hline $\begin{array}{l}\text { Air monitor fan evaluators paired to } \\
\text { DPT } 2500 \text { Plus transmitters }\end{array}$ & Air flow & $\begin{array}{l}\text { DTP } 2500-0.25 \% \text { of natural span, including } \\
\text { hysteresis, deadband, nonlinearity, and } \\
\text { nonrepeatability; fan evaluator- } \pm 2 \%\end{array}$ \\
\hline
\end{tabular}




\section{APPENDIX B. PHOTOGRAPHS OF SENSORS DEPLOYED IN TWO-STORY FLEXIBLE RESEARCH PLATFORM (FRP)}

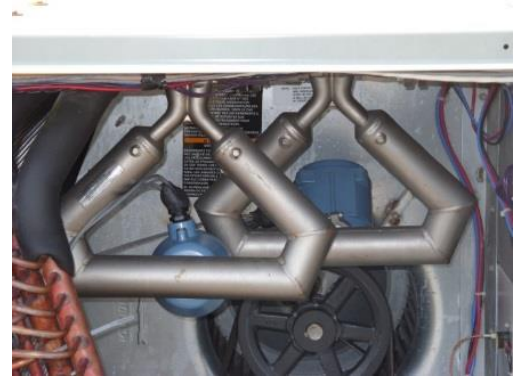

Refrigerant mass flow

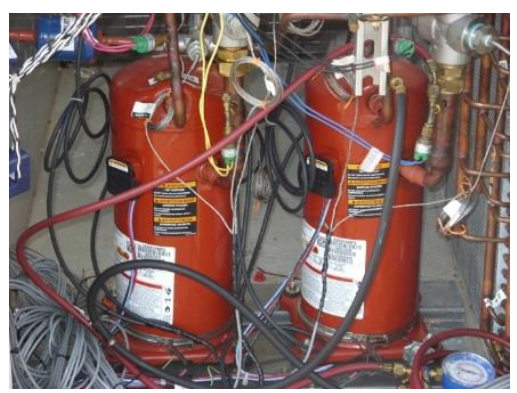

Refrigerant temperature and pressure

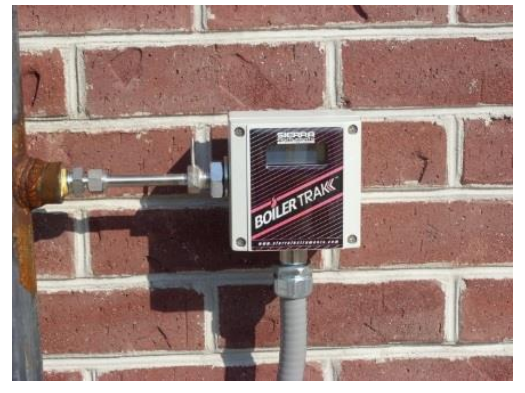

Natural gas flow

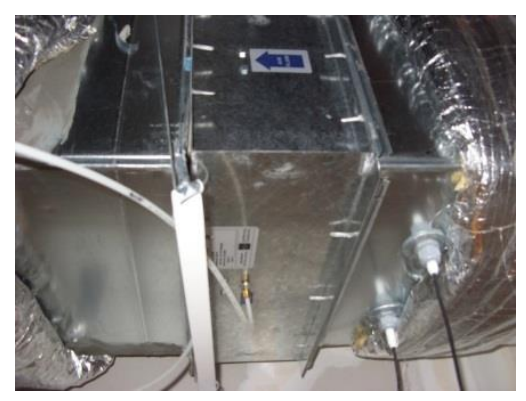

Airflow

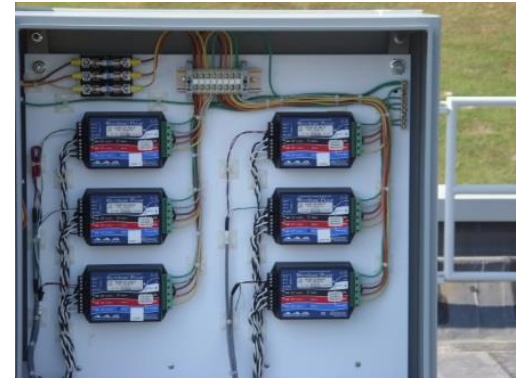

Electrical power

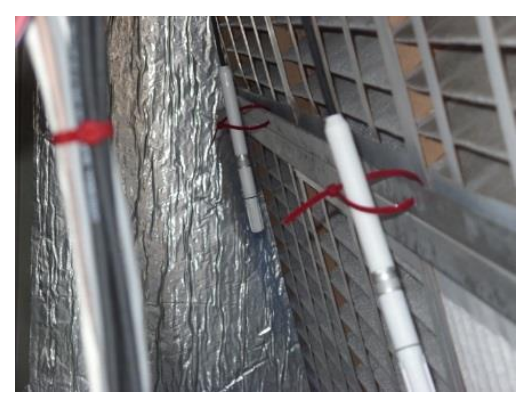

Air temperature/relative humidity 


\section{APPENDIX C. PIPING ARRANGEMENTS AND GROUND SENSOR LOCATIONS}

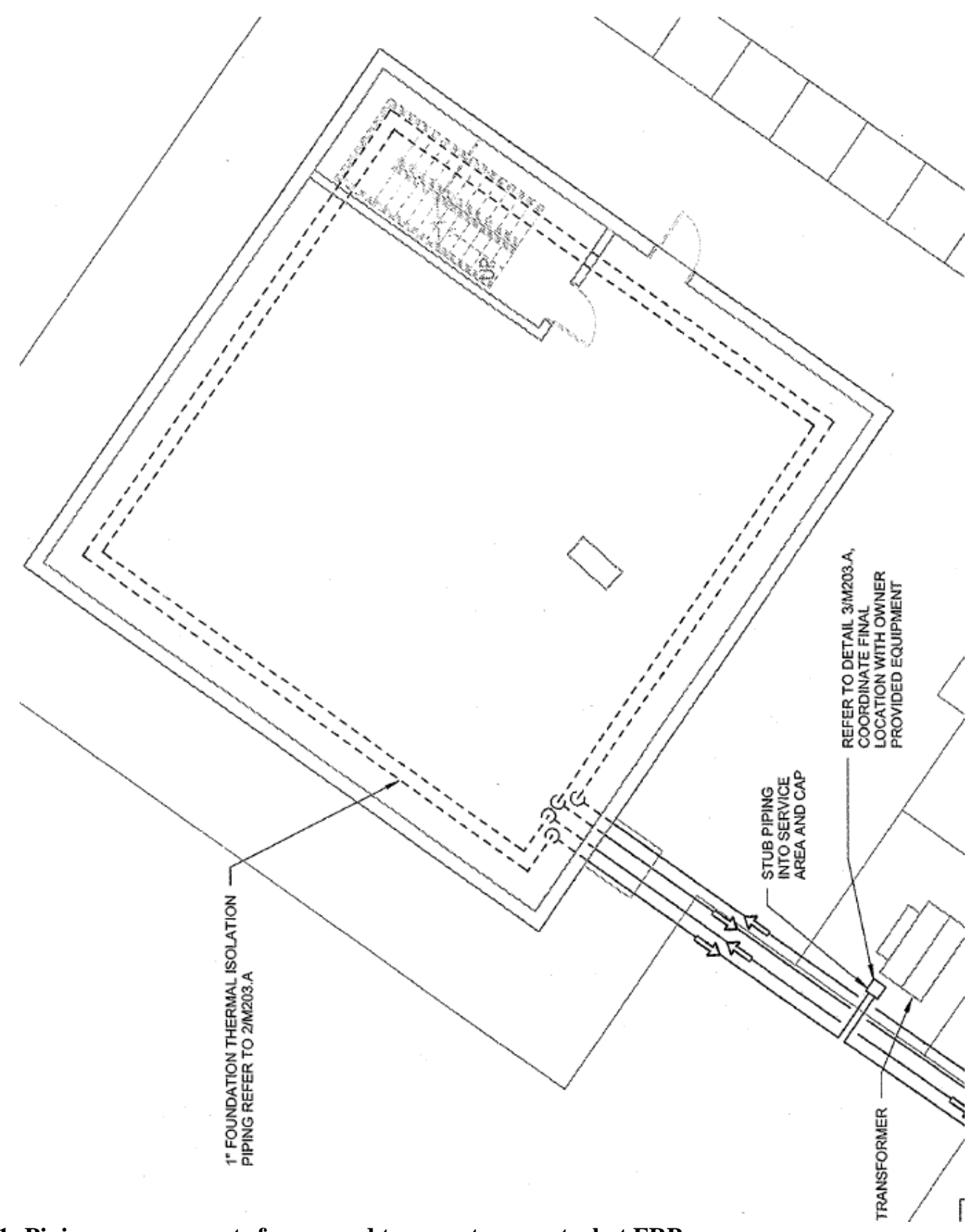

Figure C1: Piping arrangements for ground temperature control at FRP 


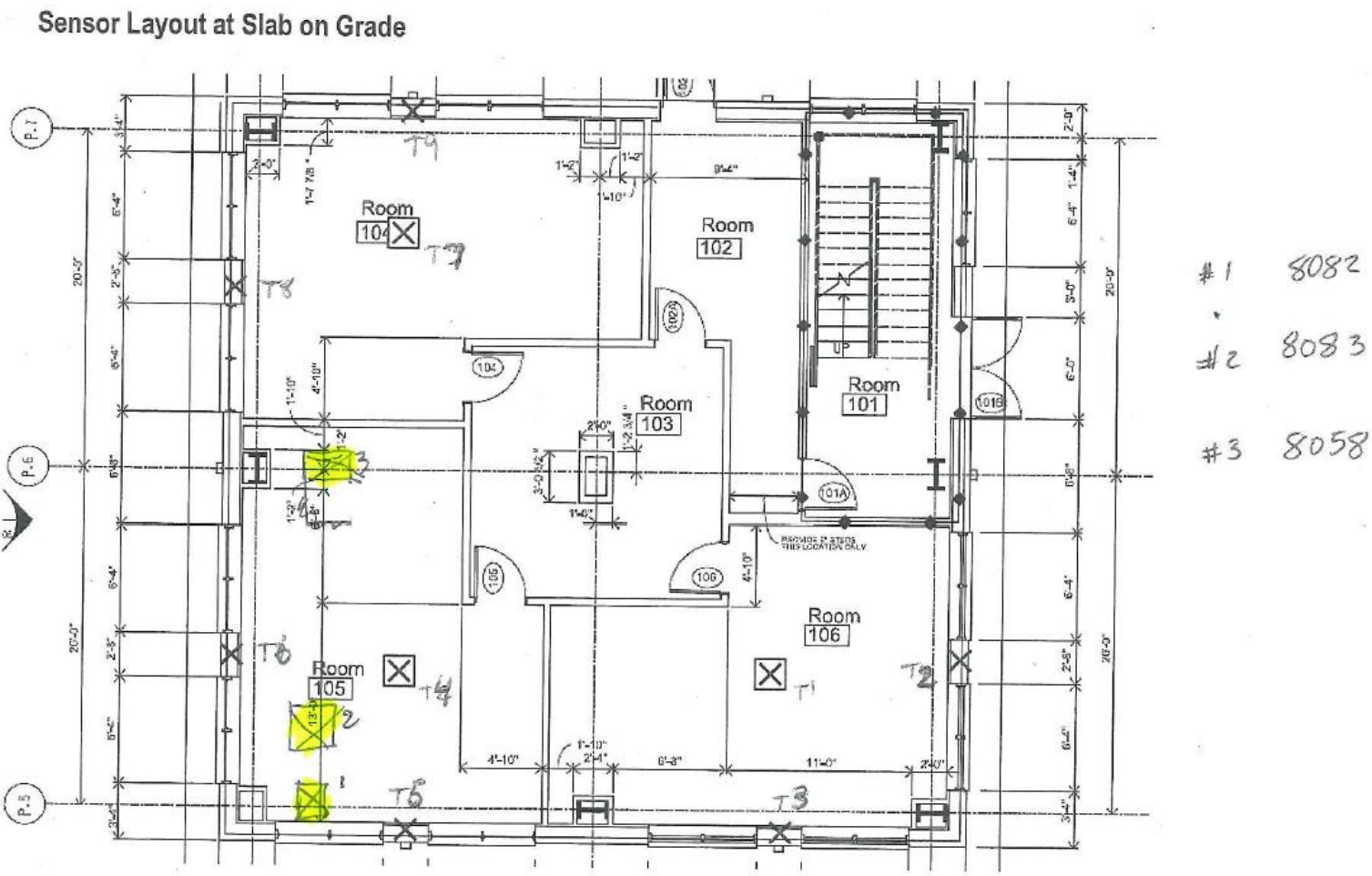

Notes:

1. Sensors at perimeter to be placed between the insulation and concrete.

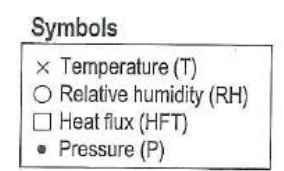

\begin{tabular}{cc}
\hline Sensor Type & Slab Total \\
\hline T & 9 \\
RH & - \\
HFT & 3 \\
P & - \\
\hline
\end{tabular}

Figure C2: Temperature and heat flux sensors locations in FRP floor 


\section{APPENDIX D. "POOR BOY” PYRANOMETER}

Pyrometers, such as Eppley's Standard Precision Pyranometer, used for global solar radiation measurements are quite expensive. Less accurate bur cheaper pyranometers such as Li-Cor's Pyrometer is another alternative for measuring global solar radiation. The researchers at ORNL developed a very cheap alternative, Poor Boy" Pyranometer. The "poor boy" pyranometer consists of a black piece of metal with a known emittance and solar reflectance, a piece of insulation, a thermistor, and a type $\mathrm{T}$ thermocouple (Figure D1). The thermistor measures the temperature of the plate, while the thermocouple measures the temperature of the insulation.

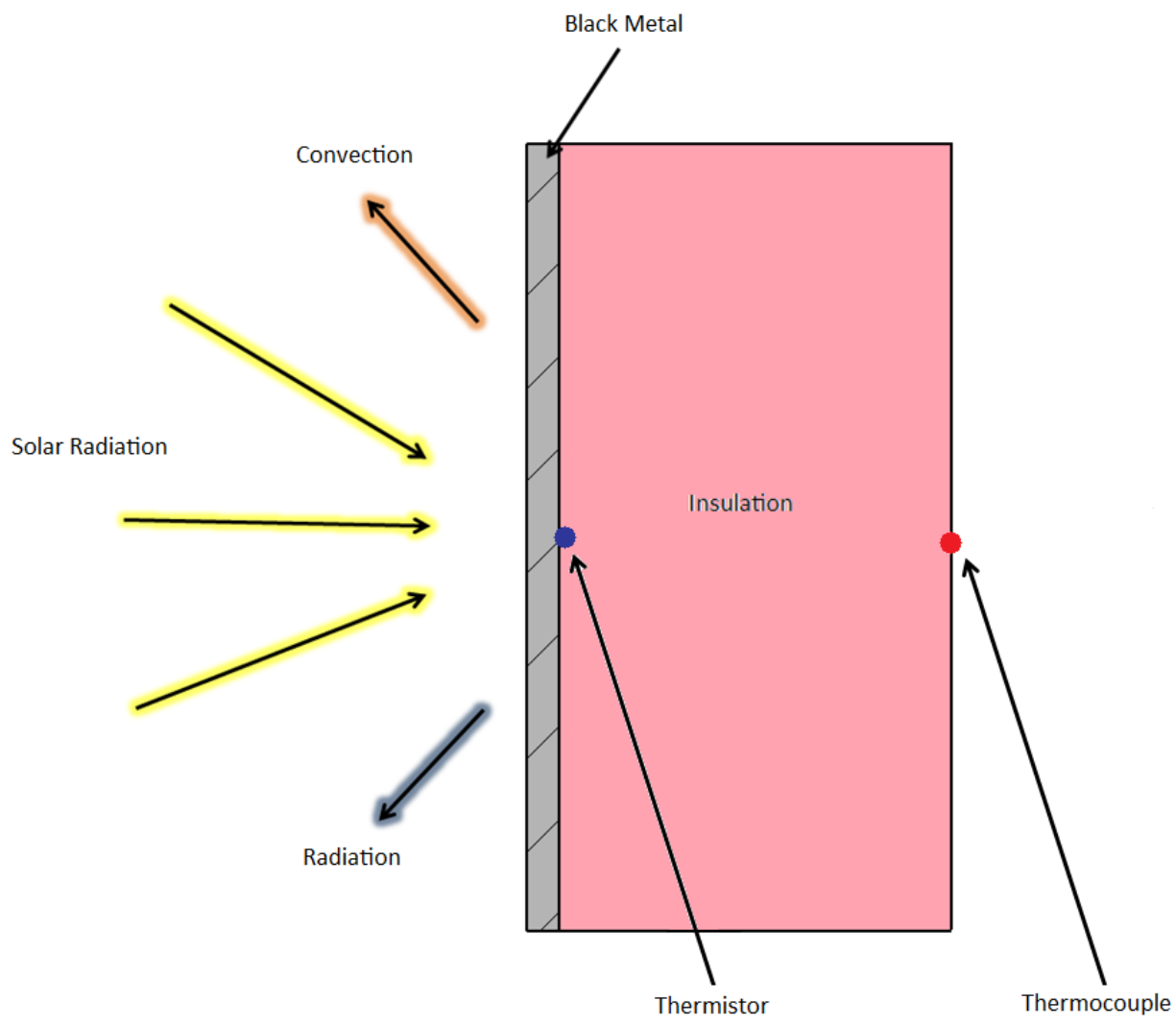

Figure D1: "Poor Boy" Pyranometer

"Poor Boy" can measure the solar radiation passing through a windows. Based on the measured temperatures, the irradiance (I) entering the zone through windows is calculated using the following equations.

$$
I(1-\rho)-h_{\text {convection }}\left(T_{\text {plate }}-T_{\text {air }}\right)-h_{\text {radiation }}\left(T_{\text {plate }}-T_{\text {room }}\right)=\frac{k \times A}{L}\left(T_{\text {plate }}-T_{\text {insulation }}\right)
$$


Figure D2 and D3 show a comparison of solar radiation transmitted through a window measured by "Poor Boy" and Li-Cor Pyranometer in January and June respectively.

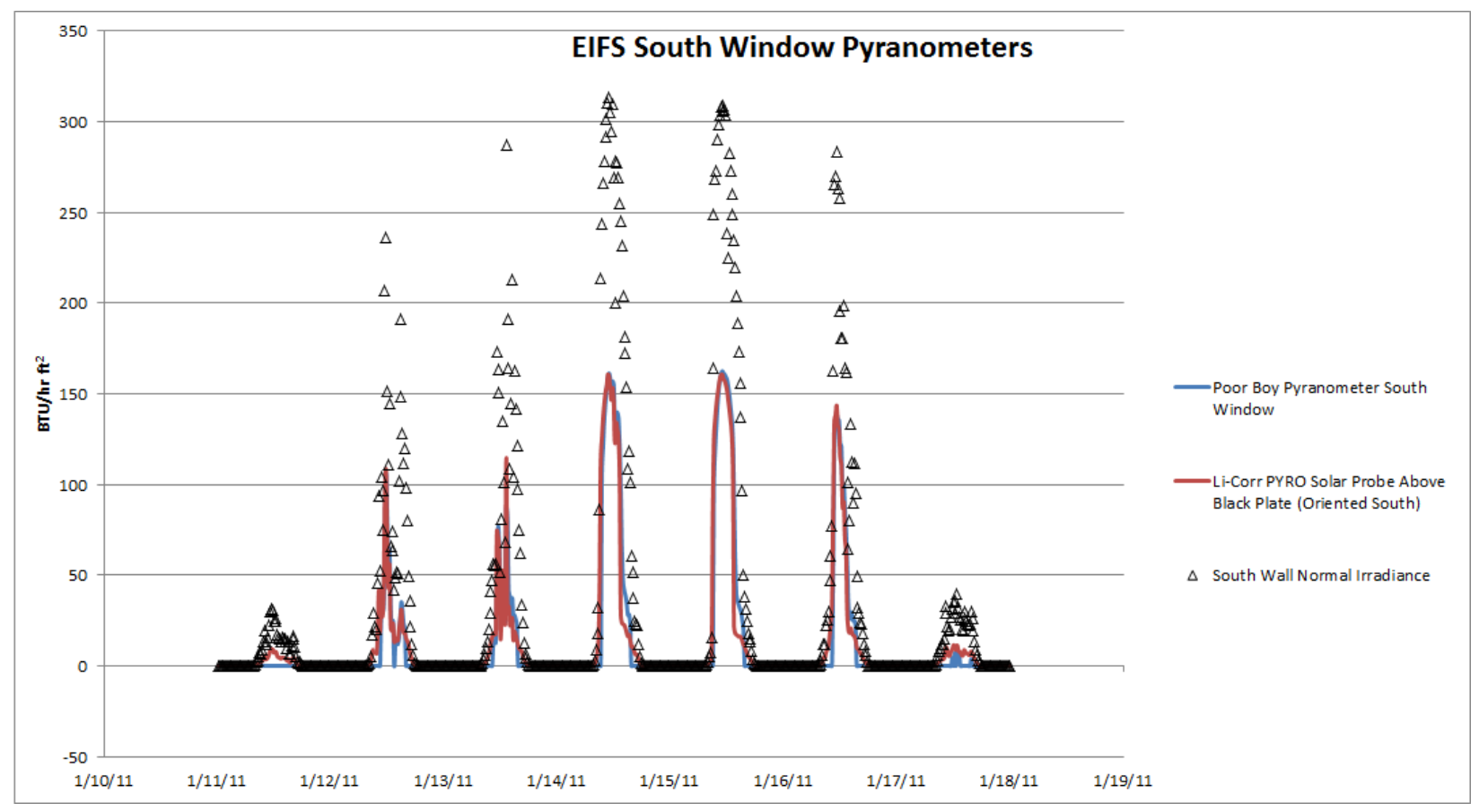

Figure D2: Comparison of solar radiation measured by "Poor Boy" and Li-Cor Pyranometers in winter

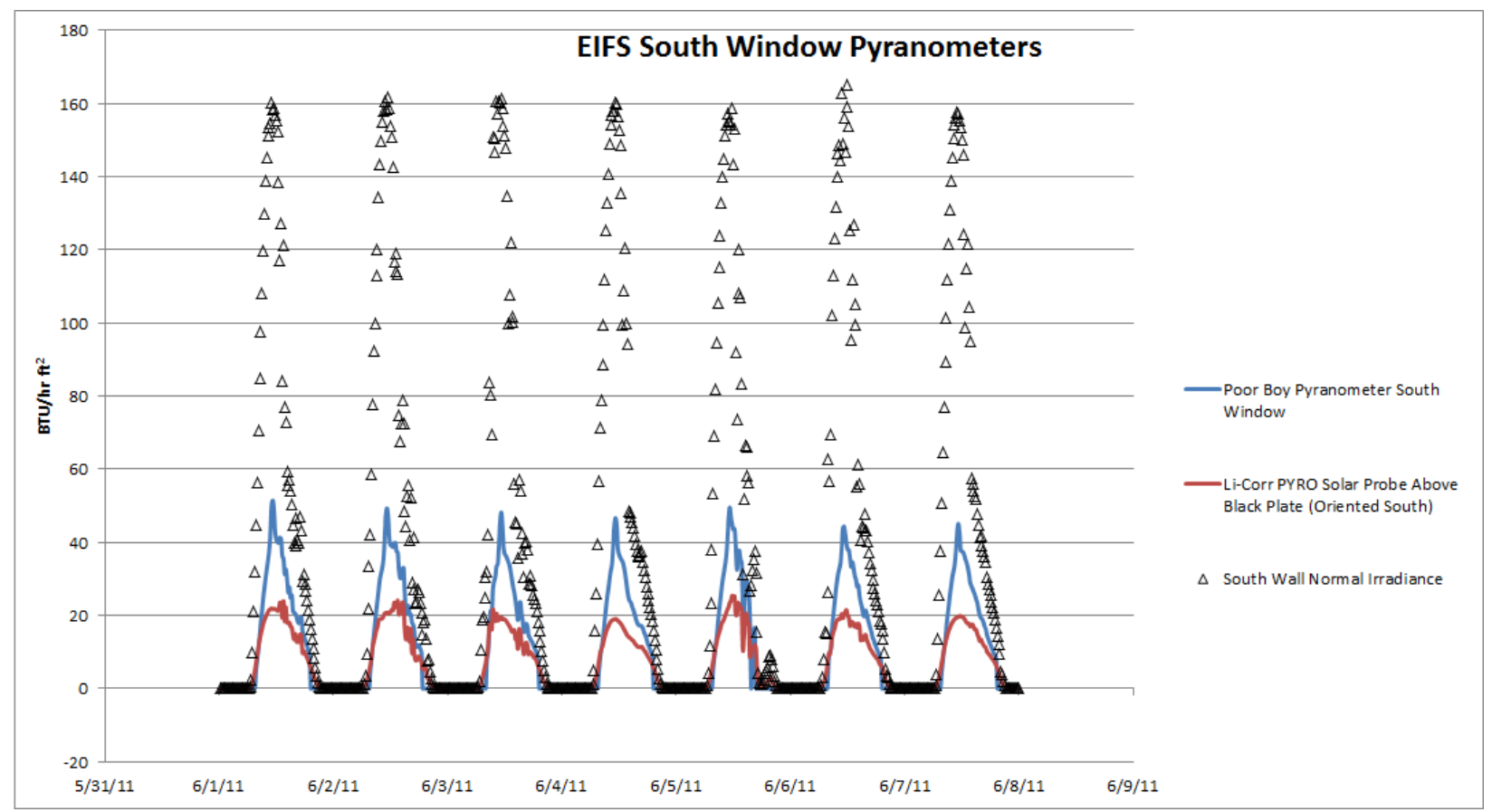

Figure D3: Comparison of solar radiation measured by "Poor Boy" and Li-Cor Pyranometers in summer

The resulst show that "Poor Boy" measurements matehces well with and Li-Cor measuremens for winter months but the measurements differ by a large margins in summer. From Figure D3, it appears that Li- 
Cor is undersetimating the transmitted solar radiation in summer. Additional investigated would need to carried out to prove the accuracy of "Poor Boy" measurements. 


\section{APPENDIX E. OCCUPANCY EMULATION}

As described earlier, the occupancy of the FRP is emulated using a typical occupancy schedule and power density for existing office buildings as defined by various sources

This appendix provides a comparison of target and measured sensible occupancy and plug load emulation and lighting emulation to ensure that the occupancy emulations were operated as planned in the initial design.

Figure E-1 compares the hourly target and emulated occupancy and plug load for a typical weekday, and the graph shows a close match. The daily total power consumption for the target and emulated loads are $71,840 \mathrm{Wh}$ and $73,529 \mathrm{Wh}$, respectively, which shows about $2.3 \%$ difference.

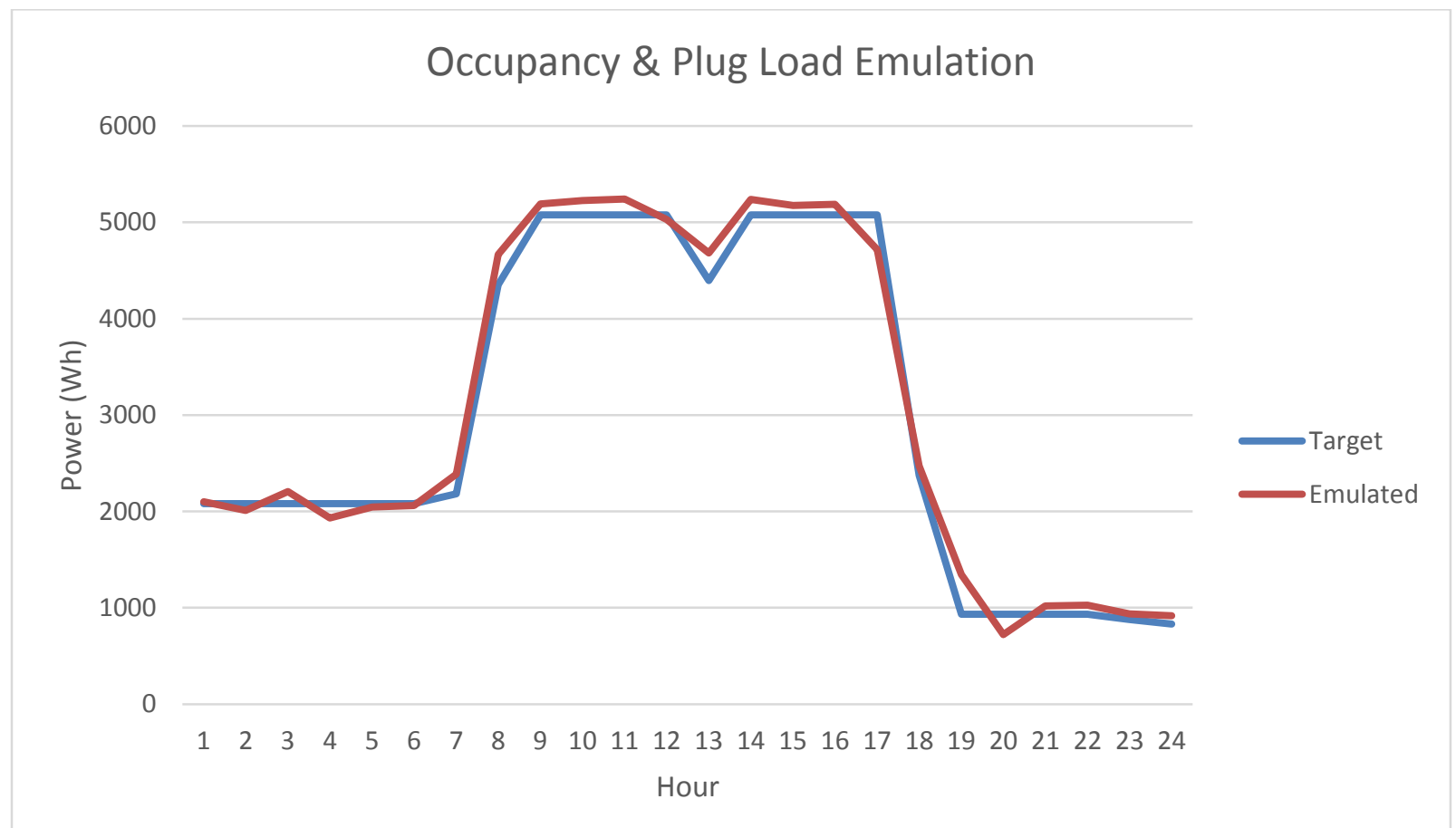

Figure E-1: Occupancy and plug load emulation: Target vs. actual

Figure E-2 compares the hourly target and emulated lighting load for a typical weekday. The daily total power consumption for the target and emulated lighting loads are 33,008 Wh and 33,848 $\mathrm{Wh}$, respectively, which shows about $2.5 \%$ difference. 


\section{Lighting Emulation}

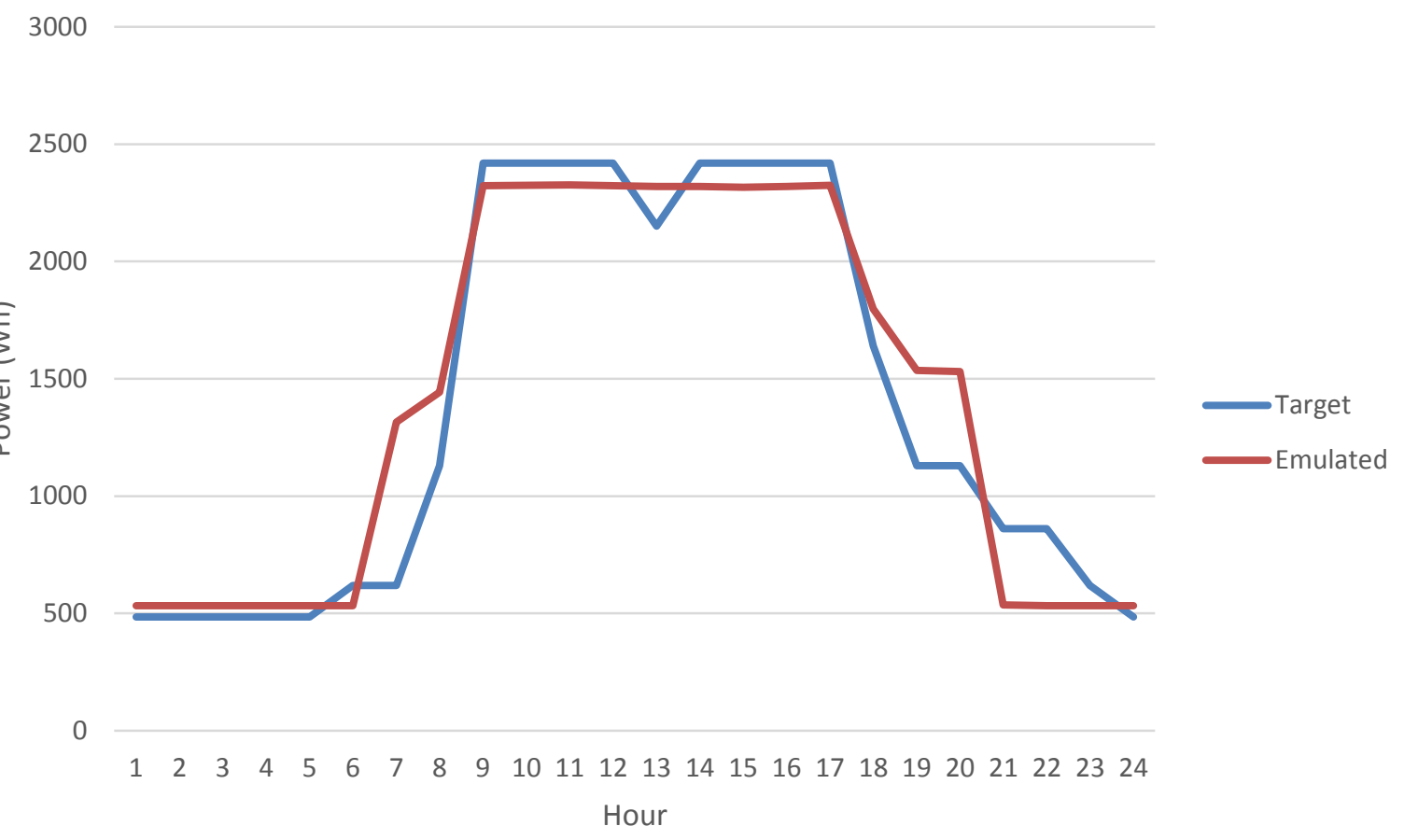

Figure E-2: Lighting emulation: Target vs. actual 


\section{APPENDIX F. BLOWER DOOR TEST}

This appendix provides a preliminary blower door test results performed for the 2 story FRP in August 2015. There has not been much change in the FRP in terms of building characteristics and HVAC systems since this blower door test. Therefore, this blower door test results will serve as a baseline for energy modeling and validation. Further blower door test will be performed once for each cooling and heating season during the validation test.

\begin{tabular}{|c|c|}
\hline Date & August 2015 \\
\hline $\mathrm{Q}_{50}$ & $1,987 \pm 1.7 \%$ \\
\hline $\mathrm{C}$ & $166.9 \pm 12.5 \%$ \\
\hline $\mathrm{n}$ & $0.633 \pm 0.035$ \\
\hline ELA & $109.3 \mathrm{in}^{2}$ at 4 Pascal \\
\hline
\end{tabular}

Where,

$\mathrm{Q}_{50}=$ Airflow at 50 pascals $\left(\mathrm{ft}^{3} /\right.$ minute $)$

$\mathrm{C}=$ Air leakage coefficient

$\mathrm{n} \quad=$ Pressure exponent

ELA $=$ Effective Leakage Area $\left(\right.$ in $\left.^{2}\right)$ 